Journal of Applied Finance \& Banking, Vol. 11, No. 6, 2021, 1-19

ISSN: $1792-6580$ (print version), 1792-6599 (online)

https://doi.org/10.47260/jafb/1161

Scientific Press International Limited

\title{
Value Analysis and Value Engineering on the Sustainability of Global Sourcing Competitiveness
}

\author{
Cheng-Wen Lee ${ }^{1}$ and Chi-Hsi Wang ${ }^{2}$
}

\begin{abstract}
In this research, the sustainability and global sourcing competitiveness of international cruise ships is studied. The sustainability and competitiveness is just like two sides of a coin. On one hand, reducing the pollution and raw material waste is not only to protect our precious nature resources, but also to bring the cost down. On the other hand, a good global sourcing decision could deliver the cost saving and also keep the cruise ship industry towards the sustainable way. Therefore, in order to reach the goals of sustainability and competitiveness, the cruise ships may apply the current common practice of value analysis and value engineering to identify the possible global sourcing opportunity. This short exploratory paper outlines some of the characteristics of value analysis and value engineering, as illustrated by sustainability of global sourcing competitiveness. Eventually, the discussion of this paper provides some implications for international cruise ship companies.
\end{abstract}

JEL classification numbers: F16, F60, Q23.

Keywords: Value Analysis, Value Engineering, Sustainability, Global Sourcing.

${ }^{1}$ Department of International Business, Chung Yuan Christian University, Taoyuan City, Taiwan.

2 Ph.D Program in Business, College of Business, Chung Yuan Christian University,

Taoyuan City, Taiwan.

Article Info: Received: August 24, 2021. Revised: September 7, 2021.

Published online: September 13, 2021. 


\section{Introduction}

Taking international cruise ships for holidays is getting popular nowadays. With more and more new cruise destinations coming to the market, the bigger and advanced cruise ships are built to meet the needs of increasing passengers. Unlike traditional tour operators, the cruise ships combine the transportation, hotels, leisure and tours. All in one service attracts many passengers who like worry-free and well-organized travels.

The modern origins of international ocean cruising have been traced back to the late 1960s and early 1970s (World Tourism Organisation, 2010). Since then, the passenger numbers have been much increasing steadily. The geography of cruising has expanded from its origins in the Caribbean to embrace the Mediterranean and the Atlantic Islands, Northern Europe, Canada and Alaska, Dubai and the Arabian Gulf, Asia and the Pacific, Australia and New Zealand, South America and Antarctica (Wood, 2000). As the popularity of cruising has grown, ownership patterns have become increasingly concentrated largely through merger and acquisition activity. Two major companies, namely the Carnival Corporation and Royal Caribbean Cruises, currently dominate the market accounting for some $47 \%$ and $23 \%$ of cruise passengers with Norwegian Cruise Lines being the third largest operator with some 10\% of all cruise passengers (Market Realist, 2015).

The larger more recently built cruise ships can carry up to 6000 passengers and offer a wide range of facilities including shops, restaurants, cafés and pubs, nightclubs, discos, casinos, art galleries and museums, theatres and cinemas, libraries, internet cafes, personal care areas and spas, solariums, gyms, swimming pools, tennis courts and ice skating rings. Onboard activities include cooking demonstrations, lectures, art seminars, organized outdoor and indoor games, bingo, karaoke, quizzes live entertainment, massage, dance classes and rock climbing. The cruise companies generally offer a variety of packages and experiences ranging from 'mini' cruises for between 2 and 5 days to round the world cruises spanning up to six months and there are 'fly and cruise' and 'cruise and stay' packages and specialist cruises including themes gay cruises and music cruises. Geographically cruises now cover virtually all areas of the world, although the Caribbean and the Mediterranean are the most popular routes, and visit over 500 destinations (Jones, Comfort, and Hiller, 2011).

The competition is focused on different cruise itineraries, ports of call, passenger's origin, size of vessels, onboard activities, all included packs, level of luxury and variety in cabins. There are very important barriers for both entry and exit in the market. High cost of building new luxury ships, global network of ships suppliers, agents and hub agents in each region and tour operators are some of the requirement for entering the market. Competition for new, small companies is very high as long as there are some large, historical companies, which control the market globally (Tsourakis, 2012). 


\section{Literature Review}

According to a December 2017 report by Cruise Industry News (CIN), the cruise industry has placed a record-breaking number of vessels on order: 91 new cruise ships are set to be debuted between 2018 and 2026. CIN's annual report additionally estimates that cruise ship vacations generated a whopping US\$35.5 billion in revenue worldwide. The report identifies the expansion of the industry into regions including East Asia and the South Pacific as a primary driver of growth, resulting in more ships, more berths, and more customers than ever before (Rossi, 2018). The world's top destinations ports are located in the Caribbean (including the Bahamas), Alaska and Mexico, while the top embarkation ports are located in the US state of Florida, for example, Miami, Port Canaveral and Fort Lauderdale (Seidl, Guiliano, and Pratt, 2007). New destination ports are being added in Asia, the Middle East, Europe and South America, as new ship-build orders have been placed for delivery well into 2007-2008. This kind of phenomenal growth was initiated by a radical change in the maritime world's registration of oceanic vessels. Aboard more than 200,000 gross tons of floating steel, thousands of passengers lounge in the sun, sip on martinis, and gorge themselves at all-you-can-eat buffets. These travelers are participating in one of the most popular new forms of vacationing, the so-called megaship: immense cruise liners with enough luxurious amenities, dining options, and invigorating activities to put even a five-star hotel to shame. But beyond new markets and new ships is a more important development: a new philosophy for success in an industry that has followed the same formula for decades. More than ever before, cruise ships are not merely a stylish way to travel from one exotic destination to another - the ships themselves have become the destination (Rossi, 2018).

\subsection{Globalization and diversification of cruise industry}

The continues growth of the world fleet, the entrance of new cruise companies, the global economic crisis, the increasing oil price, and the pressure from low costs alternative tourist sectors, forced cruise companies to reduce the prices and offer more attractive leisure packs. The increasing demands on high quality of many core business services, created the need for outsourcing some activities. Supplying cruise liners becomes more and more challenging. Issues like large lot sizes, just in time deliveries, global sourcing, worldwide operations, limitations on ports of calling and more that we discuss further in this research, increase the complexity of the cruise supply chain management. The cruise liners are vessels, luxury hotels and entertainment parks at the same time.

During a big loading in port, a cruise liner may receive frozen food and beverages from United States, hotel equipment from Germany, dry and frozen food from Netherlands, wines from Italy, fresh produce from Netherland and local market, spare parts from Italy, Germany and United States, chemicals from local market, live lobsters from Canada, casino parts from Switzerland. Normally, the food supply chain involves sourcing food through multiple suppliers and delivering the 
appropriate amount of food to seafarers on board. The food supply must be flexible, punctual, responsive and quick to formulate and implement different sourcing strategies. The food supply chain thus has become a dynamic, extensive and ever-changing entity, and attempting to cover such a broad subject is a difficult task (Lau and Yi, 2017).

All the above have to be delivered and requested in the right quality and quantity. Offering to passengers high quality services requires an efficient, robust and well-organized supply chain. At the same time, the cruise liner as a vessel requires an effective supply chain for all critical and urgent spare parts while the onboard storage capacity is limited. There is no room for a missing order and delays. The increasing demands on high quality of many core business services, created the need for outsourcing some activities. The outsourcing decision-making on important onboard departments is a continuously discussion in cruise industry. Some companies have outsourced the food and beverage department including the onboard and landside operations (Tsourakis, 2012).

Beyond the general industry trends, a number of strategies among the leading firms can be observed, including many that have relevance for local businesses in individual locations. These include the following (Daly, Fernandez-Stark, and Duke Global Value Chain Center, 2017):

1. Ocean-bound cruises are enhancing on-board amenities. Cruise companies are improving entertainment on the ship to keep consumers on board, even during port calls. While passenger tickets generally account for $70-75 \%$ of the revenue for the three leading companies, the share of onboard entertainment revenue has trended upward in recent years for all cruise lines. There is geographic disparity as well-Carnival reported that passenger income represented $72 \%$ of its revenue for North American operations in 2016 and 82\% for European consumers.

2. Cruises are expanding shore offerings in integration efforts designed to capture increasing shares of passengers' money. Cruise companies' drive toward integration also includes the development of resorts and private ports in locations throughout the Caribbean. Norwegian owns Great Stirrup Cay, which is a private island in the Bahamas, and developed the Harvest Cay destination in Belize. Carnivals owns Mahogany Bay in Honduras while Royal Caribbean has a similar venture in Mexico.

3. Cruise companies attempt to contain costs through reduction of port fees and other taxes. Cruise companies use their negotiating power to drive down costs at ports. Expenditures at each location include passenger-based fees, navigation fees, port taxes, and charges for utilities, such as water, power and sanitary services. The leverage of individual countries to negotiate higher fees is limited by the substitutability of ports and the low levels of sunk costs made by cruise companies in the form of capital investments. Attempts by individual countries to increase fees have largely been unsuccessful.

4. In considering new locations, cruise companies prioritize overall itineraries, not individual destinations. Cruise companies' negotiating power is further 
strengthened by their emphasis on selecting destinations based on overall itineraries rather than individual attractions - each piece must fit into a coherent package (Rodrigue and Notteboom, 2013). While there is not complete substitutability of port calls, cruise companies must balance the selection of destinations against operational considerations such as the sequencing of stops, the sailing schedule of ships, and the size and quality of port infrastructure. The overall implication is that the power of individual locations is often constrained by factors other than quality of tourism attractions.

Cruise ship deployments are now more than ever global. For example, with the saturation of the market, passengers are demanding new itineraries; in response, cruise lines have relocated a significant share of their fleet to the fast-growing cruising emerging market segments (CIN, 2009). Therefore, the logistical demands specific to cruise ships are many, perhaps the most salient being the global nature of their supply chains. To satisfy these demands, cruise ships must exercise a fair amount of adaptability to variability. Because the itineraries cruise ships deploy cover all main tourists markets, they must be adjusted according to seasonality and yearly demand. Different itineraries mean different operating conditions. To adapt to varying local conditions and operations, ships' agents are hired to represent the company in specific cities and to facilitate communications with local contractors and government authorities. Certain supplies are acquired locally, e.g. produce, but most are shipped from the main logistics center in Florida. The necessity for cruise ships to re-supply operations at varying, global endpoints brings with it a host of less obvious but no less important challenges (Véronneau and Roy, 2011). For example, operations must be coordinated across different time zones and brought in line with international laws and restrictions governing supplying, which vary from country to country.

\subsection{The threats of cruise industry growth}

Yet as the cruise industry embraces the over-the-top lavishness of the 21 st century megaship, divisive new questions have surfaced, some of which threaten to undermine the industry's rapid growth over the past decade. As competing cruise lines race to be at the cutting edge of the 21 st century vacation industry, the outlook for the cruise industry does not seem to be all smooth sailing. According to the United States Environmental Protection Agency (EPA), a cruise ship of 3,000 passengers can generate 150,000 gallons of sewage per week. This is a stunning figure when one considers the actual size of megaships, as some vessels can carry close to 7,000 passengers. The Friends of the Earth calculates that the EPA figure would indicate an annual production of 1 billion gallons of sewage by cruise lines. After treating waste with sanitation devices, ships release the sterilized sewage into the water. It is stressed that cruising's 'socio-economic, cultural and environmental considerations need to be continually analyzed' as a contribution to achieving sustainable tourism (Johnson, 2002). 
Some works have also been undertaken on the impact of cruise tourism in specific regions. In reviewing the negative impact of cruise tourism in Polar Regions Luck, Maher, and Stewart (2010) argued that the overall response to the environmental and social impacts had been woefully inadequate and suggest that cruise companies, governments, regulators and local communities need to work together to protect the fragile environment of the polar world. Stewart and Draper (2006) examined the elements of management and planning deemed to be important in the development of sustainable cruise tourism in Arctic Canada and concluded that stakeholders might benefit from cruise tourism management and planning being given higher priority in approaches to integrated coastal management.

However, some studies show in more pessimistic results. Brida and Zapata (2010) examined a range of the economic, environmental, social and cultural effects of cruise tourism on destinations, and by way of a conclusion, they suggested that ensuring the sustainable development of a cruise destination had a very high cost and questioned if 'the benefits of attracting cruises to a tourism destination are higher than the costs.' In addition, when a cruise ship is more than three nautical miles from the nearest shoreline, sewage is not even required to be sterilized prior to dumping. Furthermore, even after the sterilization process, sewage often contains dissolved metals and nutrients that can threaten marine ecosystems (Rossi, 2018).

\subsection{Eco-friendly and sustainable operation}

In order to meet eco-friendly and sustainable operation, although might increase the costs and expenses, the responsible cruise liners would take necessary measurements to cope with the ethics and regulations. Meanwhile, cruise company leadership need to deliver required profits to shareholders. To increase the ticket price could less the competitiveness to the business opponents, and lose the market share. Therefore, reducing the internal costs and operational expenses might provide the opportunity to maintain the competitiveness.

It is a good way for a cruise ship by using value chain analysis to carefully review and examine the internal costs and operational expenses, and amend the necessary change to reach the target savings for competitiveness. Perona (2015) described that my understanding is any 'value chain' also a 'supply chain' and vice-versa. I cannot think of a supply chain disconnected from a value chain, and the reverse is also true. So, they ought to be the same thing. What differs is the point of view. Value chain is viewed from the customer side, so the relevant aspect is the value-for-money that it can provide customers with. On the other side, the supply chain emphasizes the supplier point of view, so it is about material and information flows, costs, service level, etc.

A supply chain consists of all parties involved, directly or indirectly, in fulfilling a customer request, including the manufacturers, suppliers, warehouses, retailers and customers (Chopra and Meindl, 2004). Managing global supply chain networks is a complex task. With the current globalization of trade, supply chains are growing in importance. 
Indeed, in order to remain or to become more competitive globally, companies are increasingly outsourcing work to lower-cost regions, a practice called offshoring. As a result, companies enjoy lower production or purchasing costs but incur additional transportation, warehousing and inventory holding costs. If the savings of the former are to offset the expense of the latter, a company employing offshoring must make strategic decisions involving a host of interconnected relationships.

Procurement handles the purchase of materials or service that is necessary for the cost competitiveness of supply chain operations. Efficient procurement departments can obtain the highest quality service and materials at the lowest costs. Technology development is concerned with the technological innovation, training and knowledge that is crucial for supply chains to upgrade their capacities. In terms of firm infrastructure, firms implement corporate strategy to support overall supply chain operations. Human resource management involves recruiting qualified persons to manage the chain process so that material or service can be produced, stored and distributed under the most hygienic and controlled conditions possible. The ultimate objective is to provide customers with assurance and confidence.

The two main issues facing ships' material supply chains can be categorized as intrinsically relating to and more broadly associated with the supply chain (Lau and Yip, 2017).

Material or service quality and types are the main key issues, whereas reliability, responsiveness and assurance are the main aspects of concern in relation to the supply chain. Porter (1985) was the first to discuss the concept of the value chain in his book "Competitive Advantage: Creating and Sustaining Superior Performance" Origination in business management research. The concept of the value chain has been widely adopted other areas over the last three decades. According to Porter (1990), firms' activities can be broken down into a sequence of activities called a value chain, 'an interdependent system or network of activities connected by linkages'. When the system is managed carefully, the linkage can be a vital source of competitive advantage (Pathania-Jian, 2001).

According to Lynch (2003), value chain analysis is divided into two areas. The first discusses the value chain links concerning the value of the organization's activities within key functional parts. The second assesses the contribution of each part in the overall added value of the business. In value chain analysis, the firm is divided into primary and support activities. Primary activities are related to production, and support activities are concerned with the background necessary for the efficiency and effectiveness of the firm. In terms of support activities, procurement, technology development, and firm infrastructure are essential elements in facilitating the operations of the supply chain. A value chain analysis was adopted as the fundamental theoretical framework to evaluate the food supply chain to ships. Value chain analysis is a powerful tool for managers wanting to identify key activities and design strategic planning within the firm.

We use it to discuss competitive strategies and value to the customer in detail. The competitive strategies of firms were evident by their ability to perform better than 
their competitors on crucial activities along the supply chain. The supply chains thus maximize value creation while minimizing costs (Porter, 1985).

\subsection{Procurement and the transportation flow of global sourcing}

Diakomihalis and Stefanidaki (2012) who present some factors that determine the outsourcing of the supply chain department. The processes that are included are the procurement and the transportation flows. Diakomihalis and Stefanidaki (2012) determine that the main factors include the cruise products such as itineraries, the characteristics of a cruise ship company such as having or not a parent company, location of the activities (e.g., distribution centers), the cruisers characteristics like demographics, the total costs of a cruise and the supply strategy. They conclude that the cost is the top driver for cruise companies for outsourcing the supply chain management. Furthermore, the supply strategy is very important for larger mass cruise companies.

Global sourcing which can roughly be defined as the purchasing of goods and services from international sources, is not without risks, some temporal, some logistical (as illustrated in Figure 1). First, it necessarily increases the supply chain's total cycle time and congestion at ports. Second, capacity or quality control problems with foreign suppliers may delay product delivery. Third, increased globalization is defined by competing forces. Currently, complexity and uncertainty are unavoidable features of supply chains. In the cruise industry, supply chains are truly global. Given the nature of the tourism product offered by the cruise industry today, the supply chain functions as an integral part of the service to the consumer. To see this, one need only look at the variety of food offered to passengers on board. A cruise line cannot offer such variety and guarantee, for example, fresh produce to thousands of consumers around the world without taking into consideration the importance of such a function. Like other industries, the cruise sector is acknowledging the importance of supply chain management (SCM) by appointing high-level managers with titles such as vice-president SCM and director of logistics (Véronneau and Roy, 2011). 


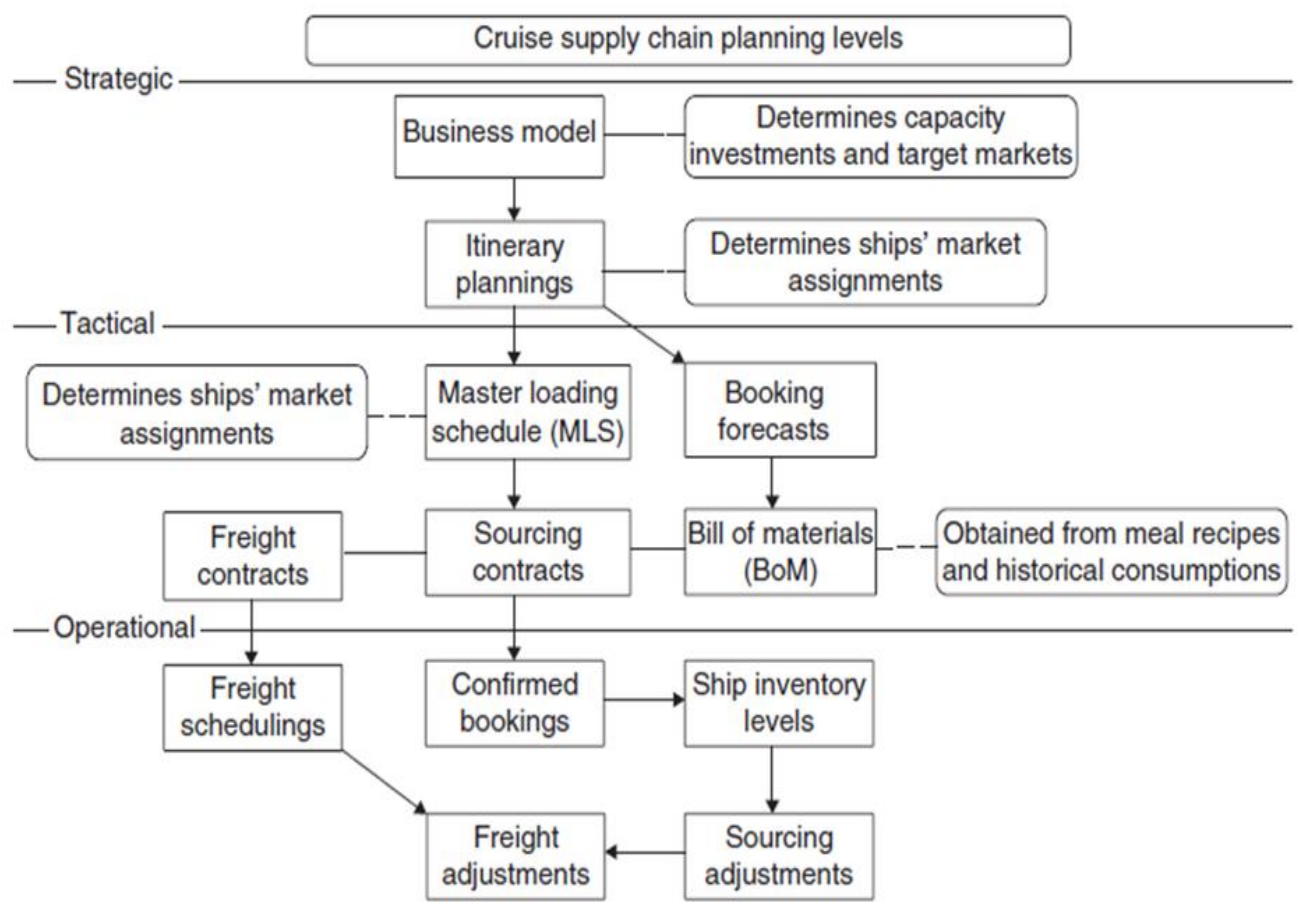

Figure 1: Supply chain management of cruise ships

Source: Véronneau and Roy (2011)

\subsection{Ford production and development system}

Like other transportation industries, the cruise ships also could also apply the current and practical methods for managing competitiveness and sustainability of the global sourcing. Among all the present existed methods, the Ford Production and Development System (FPDS) construe the essence of lean activities.

The system is modified and updated over time, and learnt by many major business entities global-wise. It seems that Henry Ford was well ahead of his time and of the Japanese, and he might have been one of the first to employ our 'newer' Japanese driven concepts (Véronneau and Roy, 2009). Some of his previous writing depicting efficiency included such statement as "having on hand twice as much material as is needed -which is only another way of saying twice as much stored human labor as needed-is precisely the same as hiring two men to do the job that one man ought to do. Hiring two men to do the job of one is a crime against humanity." (Ford, 1988) This represents the true root of lean manufacturing. It is somewhat unfortunate that when looking back at the history of Ford Motor Company, they seem to have failed to carry on the spirit of their founder in terms of productivity and leanness.

Further down within Ford's list of identified waste is the waste of packaging which is somewhat in line with Japan's present day popular concept of 'muda' as described by (Hampson, 1999). 
Henry Ford says on this matter, "Handling freight roughly is another source of great waste. It is absurd that an article for shipment has to be protected against other than the ordinary jarring of travel" (Ford, 1988). Another concept that Ford had already understood quite well in 1926 was the waste of transportation; "To carry a product five hundred miles to the consumer if that product can be found within two hundred and fifty miles is a crime. For a railroad to deliver in ten days when it might deliver in five is grand larceny" (Ford, 1988). With such comments, Ford is still very current in the issues he addresses. Today's railroads have been struggling to stay lean and on time having congestion issues so often that it causes delays in the supply chain (Reinhardt, 1998). One issue that seems to be recurring when looking at literature is the failure for managers to adopt the best practices and to exert strong leadership to avoid such waste. When reading the latter comment of Ford on distance travelled by products, we can only rethink of our current globalization phenomena and ponder on whether these supply chains that circle the world a few times while creating congestion on current infrastructure are really worth the penny saving (Véronneau and Roy, 2009).

The Japanese with the Toyota Production System (TPS) and other popular manufacturing initiatives have not invented anything new other than Ford system. However, they deserve credit for having sifted through the best management principles out there and summarized it in a very concise format. This view seems to be in line with Svensson (2001) who also believes that the Japanese took inspiration on North America for their concepts, and recognizes

Ford's old ways of management similar to our newer techniques. Perhaps the biggest mistake Henry Ford made is that he never did a point-form list of directives for his managers to follow on. It was quixotic of him to believe that the average American manager would take the time to read his whole book and make sense of his lengthy writings.

\subsection{Value analysis and value engineering of FPDS}

Although not always the case, yet value analysis (VA) and value engineering (VE) of FPDS is usually conducting through bottom-up process. The bottom-up approach delivered practical data and workable ideas through cross-functional team decision of cruise ships. The strength of the bottom-up approach is to capture the feedback and expectations of key stakeholders who are really participate in the cruise ship daily activities. Now a days, every manufacturing organization is striving to focus in lowering the production costs and reduction in material waste by VE. Material saving can be achieved only through optimizing the volume of the shape (Elia, Ridzal, and Shashkav, 2016). The engineers are prompted to look for rigorous methods of decision making such as optimization (Vijayan et al., 2019; Georgioudakis, Lagaros, and Papadrakakis, 2016; Tanlak, Sonmez, and Senaltu, 2015). As a result, value engineering methods was developed to help engineers design systems that focuses lot on efficiency \& economy and to develop innovative methods to improve the performance of the existing systems (Swartjes et al., 2017). 
Value Engineering design optimization can be classified as one of the best mathematical approach to identify and select the best set from the set of probable design alternatives

Meanwhile, VA is characterized by a creative, structured and interdisciplinary approach regulated by a work schedule developed by Society of American Value Engineers (SAVE). VA includes five major steps:

1) Information phase: concerns the identification and collection of information about the project, from its basic elements to the major information regarding project execution.

2) Functional phase: the functional structure of the VA object is outlined in order to identify and classify the fundamental customers' requirements.

3) Creative phase: some alternative solutions to the current situation are given, starting from the observations made in the previous functional phase.

4) Evaluation phase: the alternatives are compared on the basis of the value index, defined by the ratio between the worth index and the cost index.

5) Presentation phase: proposals are presented to the management and the benefits, limitations and risks related to each proposal are also explained.

The main benefit of VA lies in its high degree of participation and practice. However, researchers have also underlined several limits in VA implementation. Information collection and organization is ranked as the most frequently occurring problem (Shen and Chung, 2000). The lack of information and poorly organized data could negatively affect the development of a VA study from its beginning. VA requires strong team-work and interdisciplinary competence to face decision making. The group decisional process can be very difficult and unproductive if not managed in the proper way (Nunamaker, Vogel, and Potter, 1997). Information technology (IT) can help overcome some difficulties commonly encountered during VA implementation, such as the formalization of the problem to be addressed, the generation of selection criteria, the facilitation of cross-functional interaction, the achievement of active participation in decision analysis, and the speeding-up of the decision making process. Unfortunately, only little research has been undertaken to study and understand how it is possible to overcome these problems. Shen and Chung (2000), and Fan, Shen, and Kelly (2008) argue that decision making capability can be supported and enhanced by the use of decision support systems (DSSs) along all the stages of the decision process, from the structuring of the problem, to the selection of the proper alternative solution.

According to Zack (2007), computer-based decision support technologies are appropriate to support decision making especially under conditions of uncertainty and complexity. However, a decision support tool, based on value analysis that designers can use to document and formalize their choices and thus overcoming the above mentioned limits, still lacks. Interestingly enough, information collection and organization play an important role, not only during VA implementation. Also, at the end of VA studies there is the risk of losing important information. 
When projects call for long duration, large costs and impact on current assets, and a wide involvement of subcontractors, knowledge (e.g., on decision criteria, on solutions adopted to solve problems, etc.) generated during each project to reduce costs and/or increase value could be usefully transferred to other projects so that management teams can benefit of a formalized database of past problem solving experience.

In the VA literature there is a lack of investigation on how the knowledge base acquired and created during the execution of one VA study can be transferred and reused in succeeding projects. Instead, the most popular approach in the VA literature is focused on single independent projects (Meil, 2006; Ibusuki and Kaminski, 2007), without exploring the possibility of sharing common knowledge. This approach often leads to a non-organic and non-effective use of past experience, thus preventing exploitation of useful knowledge and past approaches (Romano et al., 2010). Although like other method, VA/VE has its limitation and constrains, the VA/VE is still a well-known structured method to increase product value and/or cut costs, and be adopted by many world-class business entities.

\section{Methodology}

The bottom-up of VA/VE approach delivers semi-quantitative data, based on stakeholder interviews (including informal conversation), questionnaire, survey, and analysis of publicly available data such as annual reports of relevant companies. The strength of the bottom-up approach is capturing both qualitative and quantitative aspects like opinions, expectations and figures of key people in the development of the competitiveness and sustainability when designing the global sourcing approaches.

In addition, cruise supplies have thousands of different commodity codes. For instance, only food and beverage department uses 1,500 product codes while engine department over 800 . The groups of supplies that a cruise liner requires are similar for all the companies. In this study, the cruise supplies are classified to five categories based on the departments that place the orders. Each department is responsible to approve the orders from the sub offices, places the order and receives the goods onboard. These five categories are the food and beverage, the hotel stores, the engine parts, the bridge items (security, environment, and so on), and the concessionaire products (casino, spa, boutiques, art, etc.). All these categories are classified in several groups depending on the type of supplies, the lead time, the transportation mode, the replenishments and the criticality (Tsourakis, 2012). Although different cruise companies have varies categories, yet the main classification is similar.

The data collection and interviews are trying to as broad as possible, and to allow for a maximum of angle to do the studies. Whereas, also ensure that critical aspects were not left out due to a narrow focus (Véronneau and Roy, 2009). Then, the data is coordinated and consolidated to further analysis. 


\subsection{Data collection and information source}

The focus of cruise ships is set on those who are with international operations and activities in and out Taiwan Keelung port. The selected sets of interviewees and are aimed at achieving a good representation of stakeholders with diversification. For logistics services, the focus is set on those currently supplying products to cruise ships. For port terminal service operators, the interviews is focused on the main players whose main business are to provide the service to the cruise ships.

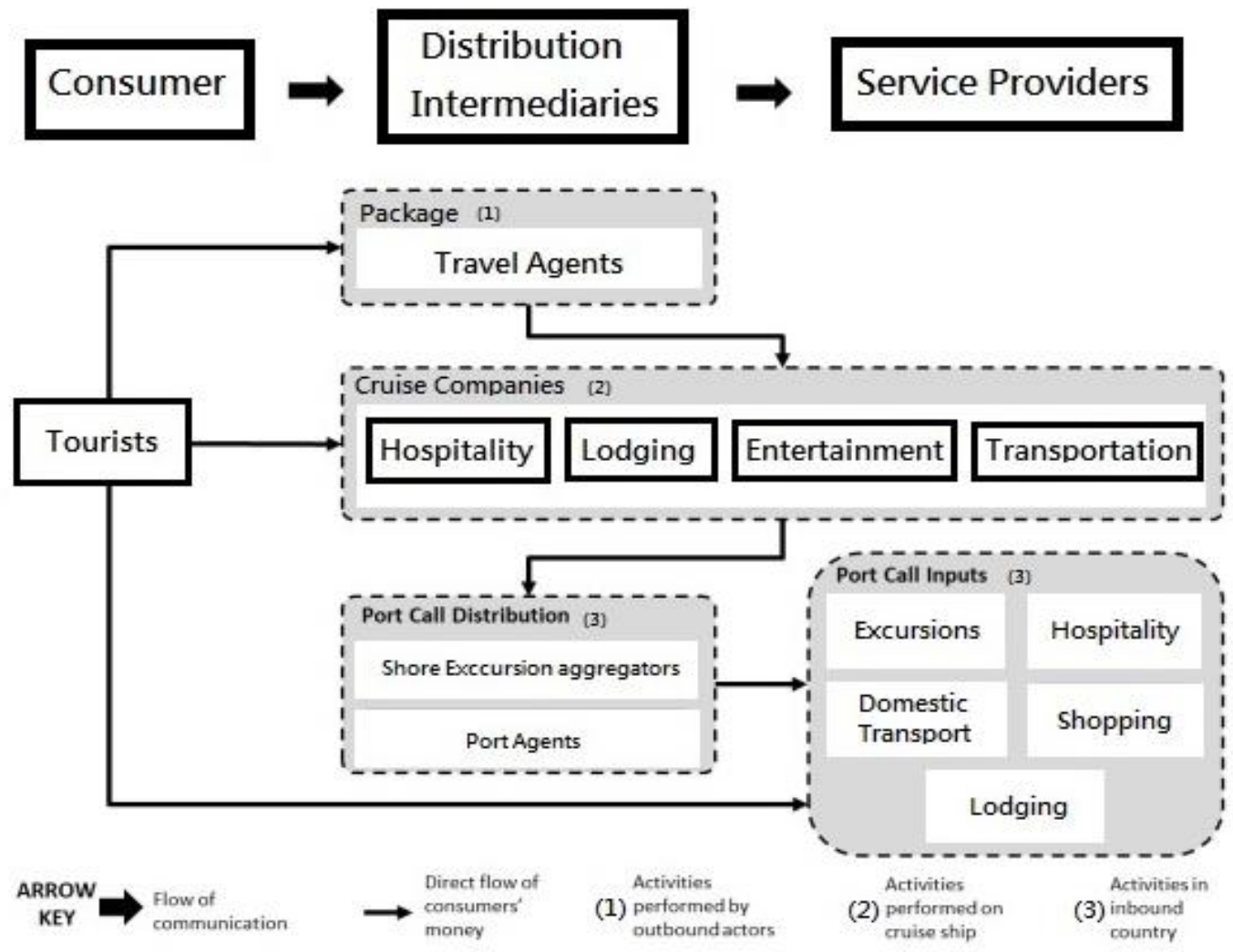

Figure 2: VA/VE method

Source: Daly, Fernandez-Stark, and Couto (2017) 


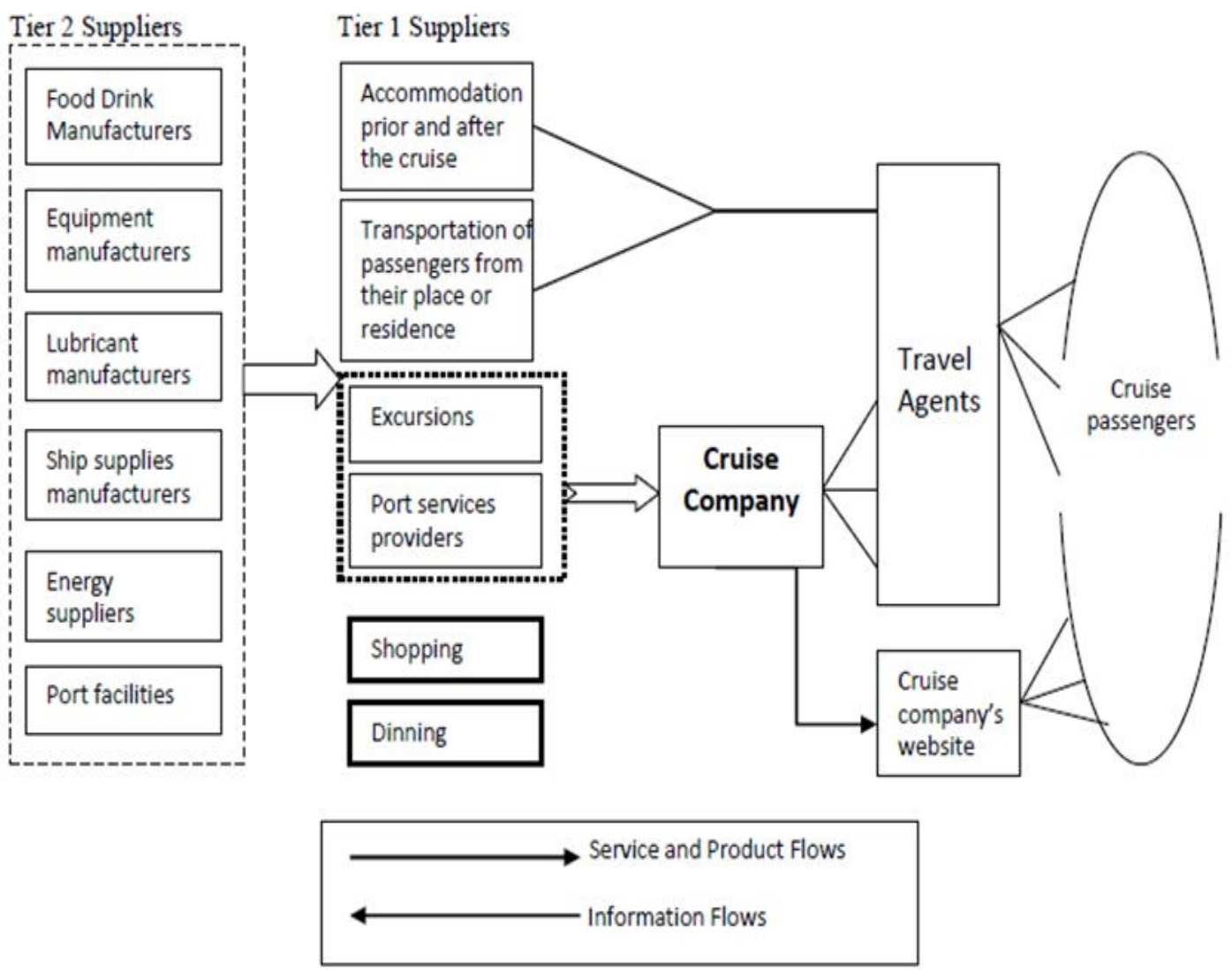

Figure 3: The role of tier 1 and 2 suppliers in VA/VE method

Source: Zhang et al. (2017)

The data for this study are collected from several sources of international cruise ships. Figure 2 shows that the VA/VE method is usually bottom-up process, the respondents and stakeholders for this study are cruise employees, tier 1 and tier 2 suppliers (see Figure 3), agents, consolidators, onshore service providers, and tourists, etc. (Zhang et al., 2009). Those publications and websites which are related to international cruise ships are also being referred to this research. In addition, the informal conversation is also a way of this study. The interview and questionnaire is based on anonymous survey in order to get the authentic answers. 


\subsection{Data analysis}

During the research, the responses received from those selected stakeholders have been considered as high enough to be considered as representative. Taking into account the fact that cost competitiveness are very attractive to the cruise ships to select destinations and suppliers, the government policies and the suppliers' market share are played at very important or important driver. Some Port management feels pressure from local authorities demanding improved air quality and to create new market opportunities. Specific drivers for Port management are energy costs and sustainability. Meanwhile, the cruise industries are looking for cheaper alternatives. Also, cruise tourist industry is emphasizing the negative impact of polluting factories on its image.

The VA/VE analytical tools can be applied in several methods. It could be used to simulate a simple supply chain at single port. It could also be used to simulate complex scenarios such as the supply and demand analysis to make global sourcing decision. The VA/VE saving allows the analytical tool to identify and calculate operational synergies between ports. Designing a supply chain requires several intuitive decisions on what logistic model to use; the tool will immediately produce an optimized proposal. Certain rules are implemented in the calculator code, but most parameters are exposed to the user and can be updated based on latest market information. In the design process, the user might choose to fix or force certain assets (vessels, terminals, and feeder) to better reflect actual market conditions (Core LNGas Hive, 2014). The VA/VE methods allow changes at later stage. Each designed scenario can be saved in the analysis tool. This VA/VE methods allows retrieving and comparing alternative solutions to meet demand from both management and customers. Using the VA/VE analysis tool, the user can determine and present the best global sourcing solution to deliver cost competitiveness and environment sustainability.

The VA/VE development allows stakeholders to design and simulate the economic and operational aspects of their own logistics chains from numerous and detailed input variables (means of supply, demand, regulated costs, port, fuel, etc.), edit the market / demand assumptions and generate a database of analyses already carried out. It allows its subsequent revision and modification (allowing the adaptation of the results to the evolution of the market), as well as generating reports and visualizations that include numerous analysis that meet the different demand scenarios. The result allows a sensitivity analysis of key operating parameters to be performed (Core LNGas Hive, 2014), Stakeholders can modify any input data. The VA/VE analytical tools provide the end user total control in the design and decision.

The VA/VE methodology has been used to analyze the competitiveness. Although with different names, yet similar methods are practiced in various industries. By taking the sustainability into account, the VA/VE methodology enhances the global sourcing decision to the meet the requirements of ethics and regulations. 
The data analysis composes of procedures:

1) General analysis of the feedback of the interviews and questionnaire.

2) A comparison between the before and after the VA/VE study.

During the procedure 1 , the primary purpose is to reduce operating costs while maintaining the service quality.

Therefore, the main questions for the target groups are:

a. What makes VA/VE so distinct to the cruise ship?

b. Which distinctive saving opportunities are available from the current commodities and services?

c. What are the challenges of managing global sourcing with dynamic supply locations? What are the best practices that could be used to and benefit other crossfunctional departments?

d. To which degree does technology contribute to the global sourcing and sustainability?

e. What is the strength and magnitude of the relationship with the suppliers and service providers?

Meanwhile, the procedure 2, in an attempt to undertake an exploratory examination of the extent to see if the VA/VE generates the environmental, social and economic impacts of their operations, it is important to address and report on their sustainability strategies and achievements of competitiveness of global sourcing. The observational research might be conducted during the voyage, which provided the firsthand opportunity to experience the results and finding of implementation at sea.

\section{Discussion and Research Limitation}

None of the involved respondents are with high confident with the feasibility of business cases for a VA/VE sourcing proposal due to the short terms of hiring contract. Also, the high crew turnover rates generate uncertainties and impact onto $\mathrm{VA} / \mathrm{VE}$ business cases. The bottom line for not investing in the VA/VE sourcing is the lack of confidence in a minimum sustainable profit margin during the fast changing policies and market environment.

The paradox is that shipping companies are expecting to promote its images with stricter environment regulations. Some shipping companies are actively improving their carbon footprint and environmental impact with low cost but high impact initiatives such as energy usage reduction and using low resistant marine coating. Cruise ship operators emphasize the importance of an environmental friendly image or reputation and perceive this as an important unique selling proposition to attract customers. However, on the other hand, they may not want the environmental regulations to be so strict that will significantly disturb current global shipping market equilibrium. This combination makes cruise companies less confident to adopt any significant amendments.

Different form the Top-Down analysis which evaluates the existing demand and supply curve for traditional commodity consumption and estimates the development of market trend in the office, yet the approach of VA/VE for global sourcing is 
applied for practical analysis by carrying out perspective views from operating levels. The confrontation of the bottom-up and the top-down analysis has resulted in an updated forecast for the different scenarios. The scenarios from the top-down analysis are mainly the results of an independent and mostly objective analysis, but also largely theoretical in nature. So, the combination of the results from the bottom-up approach and the top-down approach is the key way to make VA/VE more feasible and workable between management and working level, and this will be taken into the future study.

Some interviewees might hesitate to provide the research data due to their internal rules or high moral standards. Therefore, in order to courage the interviewees more willingly to respond this research, all participants will be anonymous.

\section{References}

[1] Brida, J.G. and Zapata, S. (2010). Cruises tourism: Economic, socio-cultural and environmental impacts. International Journal of Leisure and Tourism Marketing, 1(3), pp. 205-226.

[2] Chopra, S. and Meindl, P. (2004). Supply Chain Management: Strategy, Planning, and Operations. Upper Saddle River, 2nd ed. New Jersey: Pearson Prentice Hall.

[3] CIN, 2009, 2017, Cruise Industry News, https://www.cruiseindustrynews.com/pdf/

[4] Core LNGas Hive, 2014, Project info 1, LNG demand and supply logistics chain (Mediterranean, Atlantic and Gibraltar Straitperipheral regions), Connecting Europe Facility (CEF) Transport Call.

[5] Daly, J., Fernandez-Stark, K., and Center, Duke Global Value Chain (2017). Barbados in the cruise tourism global value chain. Technical Report, August 2017.

[6] Diakomihalis, M. and Stefanidaki, E. (2012). Cruise ship Supply chain: A field study on outsourcing decisions. International Journal of Decision Sciences, Risk and Management, 3, pp. 369-383.

[7] Elia, M.D., Ridzal, D. and Shashkav, M. (2016). Optimization-based mesh correction with volume and convexity constraints. Journal of Computational Physics, 313, pp. 455-457.

[8] Fan, S., Shen, Q., and Kelly, J. (2008). Using group decision support system to support value management workshops. Journal of Computing in Civil Engineering, 22(2), pp. 100-113.

[9] Ford, H. (1988)). The Meaning of Time. In Today and Tomorrow, Reprint Edition. Productivity Press.

[10] Georgioudakis, M., Lagaros, N.D., and Papadrakakis, M. (2016). Probabilistics shape design optimization of structural components under fatigue. Computers and Structures, 182, pp. 252-256. 
[11] Hampson, I. (1999). Lean production and the Toyota production system or, the case of the forgotten production concepts. Economic and Industrial Democracy, 20(3), pp. 369-391.

[12] Ibusuki, U and Kaminski, P.C. (2007). Product development process with focus on value engineering and target-costing: A case study in an automotive company. International Journal of Production Economics, 105(2), pp. 459474.

[13] Johnson, D. (2002). Environmentally sustainable cruise tourism: A reality check. Marine Policy, 26, pp. 261-270.

[14] Jones, P., Comfort, D., and Hiller, D. (2011). Sustainability in the global shop window. International Journal of Retail \& Distribution Management, 33(12), pp. 882-892.

[15] Lau, Y.-Y. and Yip, T.L. (2017). The procurement of food on board liner ships: The role of the international labor organization, Journal of Shipping and Trade, 2(6), pp. 1-14.

[16] Luck, M., Maher, P, and Stewart, E.J. (2010). Cruise Tourism in Polar Regions. Earthscan: London.

[17] Lynch, R. (2003). Corporate Strategy, 3rd ed. Financial Times, Prentice Hall.

[18] Market Realist (2015). A key overview of carnival, the World's Largest Cruise Company, available at http://marketrealist.com/2015/01/carnival-boasts-largest-market-share-cruise-passengers/ (Accessed 26 November 2015)

[19] Meil, J. (2006). A life cycle environmental and economic assessment of optimum value engineering in houses. Forest Products Journal, 56(9), pp. 19-25.

[20] Nunamaker, J.F., Jr., Vogel, D.R., and Potter, R. (1997). Individual and team trends and implication for business firms. Advances in the Study of Entrepreneurship, Innovation, and Economic Growth, 9, pp. 199-247, JAI Press, Inc.

[21] Pathania-Jian, G (2001). Global parents, local partners: A value-chain analysis of collaborative strategies of media firms in India. Journal of Media Economics, 14(3), pp. 169-187.

[22] Porter, M.E. (1985). Competitive Advantage: Creating and Sustaining Superior Performance. Free Press, New York.

[23] Porter, M.E. (1990). The Competitive Advantage of Nations. Free Press, New York

[24] Reinhardt, F. L. (1998). Environmental product differentiation: Implications for corporate strategy. California management review, 40(4), pp. 43-73.

[25] Rodrigue, J. P. and Notteboom, T. (2013). The geography of cruises: Itineraries, not destinations. Applied Geography, 38, pp. 31-42.

[26] Romano, P., Formentini, M., Bandera, C., and Tomasella, M. (2010). Value analysis as a decision support tool in cruise ship design. International Journal of Production Research, 48(23), pp. 6939-6958.

[27] Rossi, M. (2018). Cruising the high seas: Luxury vacations face uncertain future. Harvard International Review, 39(2), pp. 24-29. 
[28] Shen, Q. and Chung, J.K.H. (2002). A group decision support system for value management studies in the construction industry. International Journal of Project Management, 20(3), pp. 247-252.

[29] Seidl, A., Guiliano, F., and Pratt, L. (2007). Cruising for colones: Cruise tourism economics in Costa Rica. Tourism Economics, 13(1), pp. 67-85.

[30] Stewart, E.J. and Draper, D. (2006). Sustainable cruise tourism in Arctic Canada: An integrated coastal management approach. Tourism in Marine Environments, 3(2), pp. 77-88.

[31] Svensson, G. (2001). Just-in-time: The reincarnation of past theory and practice, Management Decision, 39(10), pp. 866-879.

[32] Swartjes, L., Etman, L. F. P., van de Mortel-Fronczak, J. M., Rooda, J. E., and Somers, L. J. A. M. (2017). Simultaneous analysis and design based optimization for paper path and timing design of a high-volume printer. Mechatronics, 41, pp. 82-89.

[33] Tanlak, N., Sonmez, F., and Senaltu, M. (2015). Shape optimization of bumper beams under high-velocity impact loads. Engineering Structures, 95, pp. 4960.

[34] Tsourakis, C. (2012). An Analysis of Cruise Supply Chain Management in European Region: The Outsourcing Decision Making of Food and Beverage Department (Doctoral dissertation, MSc Thesis, Erasmus University Rotterdam).

[35] Véronneau, S. and Roy, J. (2009). Global service supply chains: An empirical study of current practices and challenges of a cruise line corporation. Tourism Management, 30(1), pp.128-139.

[36] Véronneau, S. and Roy, J. (2011). Cruise lines' purchasing and logistics management. Vogel, M., Papathanassis, A., and Wolber, B. (eds). Business and Management of Ocean Cruises (Chapter 7, pp.296), 1st ed., Cruise Industry Research, CABI.

[37] Vijayan, R., Geetha, T. T., Nishanth, B., Tamilarasan, M., and Kumar, V. V. (2019). Value engineering and value analysis of rear air spring bracket. Materials Today: Proceedings, 16, pp. 1075-1082.

[38] Wood, R.E. (2000). Caribbean cruise tourism. Annals of Tourism Research, 21(3), pp. 345-370.

[39] World Tourism Organisation (2010). Cruise Tourism: Current situation and Trends, available at https://pub.unwto.org/WebRoot/Store/Shops/Infoshop/

[40] Zack, M.H. (2007). The role of decision support systems in an indeterminate world. Decision Support Systems, 43(4), pp. 1664-1674. 